Article

\title{
Economic Evaluation of the Management of Municipal Firms at the Level of Rural Local Self-Governments (Case Study)
}

\author{
Peter Ágh ${ }^{1}$, Roman Vavrek ${ }^{2}$ (D), Marek Dvořák ${ }^{3}$ (D) and Viera Papcunová $4,5, *$ (D) \\ 1 Department of Public Administration, Faculty of European Studies and Regional Development, \\ Slovak Agriculture University in Nitra, 94976 Nitra, Slovakia; peter_agh@yahoo.com \\ 2 Department of Public Economics, Faculty of Economics, VŠB-Technical University of Ostrava, \\ 70200 Ostrava, Czech Republic; roman.vavrek@vsb.cz \\ 3 Department of Trade and Finance, Faculty of Economics and Management, Czech University of Life Sciences \\ Prague, 16500 Prague, Czech Republic; dvorakmarek@pef.czu.cz \\ 4 Institute of Economics and Management, Faculty of Natural Sciences, Constantine the Philosopher University \\ in Nitra, 94974 Nitra, Slovakia \\ 5 Department of Regional Economics and Administration, Faculty of Economics and Administration, \\ Masaryk University, 60200 Brno, Czech Republic \\ * Correspondence: vpapcunova@ukf.sk; Tel.: +421-37-6408-725
}

Citation: Ágh, Peter, Roman Vavrek, Marek Dvořák, and Viera Papcunová. 2021. Economic Evaluation of the Management of Municipal Firms at the Level of Rural Local Self-Governments (Case Study). Economies 9: 130. https://doi.org/ 10.3390/economies 9030130

Academic Editor: Burcin Yurtoglu

Received: 28 May 2021

Accepted: 25 August 2021

Published: 9 September 202

Publisher's Note: MDPI stays neutral with regard to jurisdictional claims in published maps and institutional affiliations.

Copyright: (c) 2021 by the authors. Licensee MDPI, Basel, Switzerland. This article is an open access article distributed under the terms and conditions of the Creative Commons Attribution (CC BY) license (https:// creativecommons.org/licenses/by/ $4.0 /)$.

\begin{abstract}
The municipality generally uses its property to perform self-governing functions, and public or business activities. In the conditions of the Slovak Republic, the municipality operates either as a legal entity in its own name or carries out business activities with the help of a contributory and budgetary organization or business firm established by the municipality. Revenues from business activities form an important part of the revenue of local self-government budgets. The aim of this paper was an economic evaluation of the management of municipal firms at the level of rural local self-governments in the conditions of the Slovak Republic on the basis of selected economic indicators. At the same time, we analyzed the relationship between selected economic indicators in relation to the size, lifespan and number of employees of the firm. The analysis was performed in the time period 2015-2019 on a sample of municipal firms at the level of rural local self-governments. For the analysis, we used selected mathematical-statistical methods (Shapiro-Wilk test, Kruskal-Wallis test, and regression analysis). The analysis showed that the differences in the profitability of municipal firms from the point of view of the region in which they operate as well as from the point of view of the number of employees is not statistically significant. Statistical significance was not demonstrated even within the volume of revenue of municipal firms from the point of view of the region in which the municipal firm operates. The volume of revenues of municipal enterprises with the population of the municipality as well as the length of time of operation on the market is growing, but these are not the only factors on which these results depend.
\end{abstract}

Keywords: municipal firms; business; economic evaluation; local self-government; rural municipalities

\section{Introduction}

In several countries, especially in western and central Europe, local self-government is independent, and direct state interference in its competences is prohibited (Aleksee 2013). However, Zhang et al. (2020) note that when local self-governments have sufficient fiscal autonomy, decentralizing fiscal power to sub-provincial governments is found to have a greater impact on increasing marketization and market efficiency. Moreover, in the environment of modern liberal democracies, there is an ever-increasing trend towards the application of the subsidiarity system (Levický et al. 2019; Pauličková 2010). On the other hand, there is a theory that the provision of financial needs of local self-government should be set in proportion to the performance of its competencies and tasks (Oplotnik et al. 2012; Klimovský 2008). Revenues of self-governing budgets generated through 
the use of the self-governing property for business purposes contribute to increasing the financial independence of local self-governments. In recent years, the business of local self-governments has proved to be one of the central interests of public administration worldwide. Local self-governments are expected to play a broad and proactive role in supporting local economic development, in addition to performing traditional public service functions. To achieve this, they must constantly innovate to attract talent and investment in the process of meeting the needs of the people in their jurisdictions through the provision of public services (Mei et al. 2016). According to Mbecke (2015), to define and generalize the phrase municipal business is not easy at all. According to him, conducting business in municipalities is not easy for two reasons. First, business is limited and still a subject of research. Second, the management of public services is also an area where much remains to be explored, including in the area of public sector business. Municipal business is a scientific discipline that seeks to understand the extent to which local self-governments and their representatives shape the discovery, creation, exploration, exploitation, and diffusion of new opportunities and the economic, social, and environmental consequences. Although public sector business capacities have not been comprehensively examined, it is worthwhile to start with some features that can contribute to the success of business at the local level. We can understand the business activity of the municipality in a narrower or broader sense. In a narrower sense, we can understand the combination of "municipal business" only as the municipality's own business activity. In a broader sense (from the point of view of using public property), we can also understand the business activity of legal entities established or funded by the municipality and legal entities in which municipalities participate with property as business deposit (Hudec 2011). By conducting business, municipalities secure part of their revenue, and at the same time, they create a competitive environment for other entrepreneurs. Municipal firms also participate in creating activities that are necessary for the municipality in terms of complexity. Gorzelak (2019) states that, in addition to revenue, municipal firms also directly create job opportunities for the inhabitants of the municipality in which the municipal firms have their registered office, which improves the overall image of the municipality. This is also confirmed by Babun (2020), who states that local self-government with adequate administrative and financial autonomy has the ability to find and attract labor power for municipal firms, which also ensures the growth of human capital in the area. Entrepreneurial activity enables municipalities to cooperate with other municipalities to solve development programs that they cannot implement from their own resources (e.g., construction and operation of a municipal solid waste landfill). This form of using municipal property can be decided by the municipal council or the mayor. The municipality is obliged to set aside the property used for business, keep it in special records and to depreciate it in accordance with the accounting for the municipality's business activities. Decision making in the management of municipal property in the Slovak Republic is the competence of the municipal council and the mayor of the municipality, who can decide on the market method or non-market method of management. In the market method of management, local self-government prioritizes revenue generation with the main goal of strengthening the local budget. In non-market management, the local self-government uses the municipal property to fulfil its competencies arising from the law, while the social characteristics of the provided goods are preferred, and the generation of revenue has only a secondary role. According to Bumbalová et al. (2021), the main purpose of municipal firms should be to carry out economic activities in the public interest. On one hand, this does not automatically exclude activities unrelated to the competences of self-government; on the other hand, self-government favors the achievement of social well-being over profitability.

\section{Theoretical Background}

The theory of business emerging in the public sector is an unmistakable sign that it is difficult to draw the line between the private and public sectors. Additionally, the municipal firm is one of the elements that, by nature, are located at the intersection between 
these two sectors (Bumbalová 2011). This is also confirmed by Vinnari and Näsi (2008), who state that municipal firms in Finland are, therefore, explicitly at the intersection of private and public organizations, as they fulfill primary commercial objectives, are an integrated organizational unit of local self-government and are covered by local legislation. However, Pirošík (2014) notes that in such a firm there may be a possible conflict of public and private interest. He states this in the example of Slovak municipal firms. Slovak legislation does not prohibit the combination of the performance of functions in the legislative and executive bodies of the municipality with activities in municipal firms. Although such a situation is often desirable, especially in the case of the mayor, as he is the statutory body of the municipality and bears direct responsibility for it, it is not possible to overlook the related problems that arise. These elements are contained in the concept of the socalled municipal firm, which Stoilova (2010) and Fil'a et al. (2020) define as an entity engaged in economic activities that are beneficial for society but unprofitable for the private sector; beneficial to the private sector, but cannot be implemented by that sector; natural monopolies. This is also confirmed by the research of Bumbalová and Balážová (2014), who note that approximately half of municipal firms are engaged in activities directly related to self-government competencies, and the other half of firms have differently oriented main subjects of activity. However, the direct provision of public services for the inhabitants, which were identified in the questionnaire as municipal services, was mentioned by only $9 \%$ of firms, another $13 \%$ stated a combination of municipal services and another focus. It follows that municipalities do not set up their municipal firms primarily for the purpose of providing services to the inhabitants, but search for ways to manage property (33\% of firms), or try to generate their own funds through profits of firms operating in the market, outside the sphere of public services. This is also confirmed by Klimovský (2008), who notes that under certain conditions, municipal firms are governed by the motive of profit and competitiveness. This is also confirmed by Stoilova (2010), according to whom municipal firms are able to profitably produce goods and provide services and also compete in the conditions of the private sector. Another confirmation of this is by Clifton et al. (2010), who state that some municipal firms in Italy have managed to achieve such a degree of competitiveness that they have also penetrated global markets (e.g., energy companies from Milan and Brescia), and their stocks have appeared on the stock exchange. However, Bumbalová (2011) notes that in the case of municipal firms, the profitability aspect may not play a key role. Municipalities often seek to provide local public services for inhabitants through a municipal firm. It is precisely this role that is the base of these firms, as opposed to firms operating in a competitive private sector. The framework of the private sector, therefore, does not seem to be a completely satisfactory context for the placement of the term "municipal firm". It is in this context of several different views of the authors on the municipal firm that we decided to focus in our research on the profitability of municipal companies in terms of individual identification factors (region, number of employees, municipality size, and longevity).

Hypothesis 1 (H1). We assume statistically significant differences in the profitability of municipal firms in terms of individual identification factors ( $a$-region and $b$ - number of employees).

Hypothesis 2 (H2). We assume a statistically significant linear dependence of the profitability of municipal firms on individual identification factors (a-size of the municipality and b-longevity).

Fölster et al. (2016) adds that some municipalities have a large number of municipal firms, which on the one hand, provides private consumption and, on the other hand, competes with private firms or tries to push private firms out of the market. Nevertheless, it is possible to perceive a municipal firm from the point of view of building local self-government for several key reasons: they create stable and quality jobs for community members; they increase local economic stability by reducing local self-government dependence on private firms; they often provide goods and services to areas lacking access that are overlooked for profit-only service providers; they often provide goods and services 
to local people at a lower cost than providers providing profit-only services; they generate new local revenues that can be used for other self-government expenses; they often provide greater reliability, transparency and democratic control than providers providing profit-only services (Community-Wealth ORG 2018). Achieving and adhering to all of the abovementioned principles is not an easy task in the environment of municipalities. From a theoretical point of view, these problems are dealt with in business theory, which is understood as a critique of the bureaucratic approach to public administration. The basis of this theory is to find a way to systematically avoid a collision between allocation economy and efficiency, on one hand, and inefficiency of use, on the other. The starting point is in the environment of business management (Osborne and Gaebler 1993). Kraftová (2002) devotes much of her own theory to a municipal firm, stating that it is an economic entity that provides products without a profit motive and without the driving force of market competition. On the other hand, she argues that since these firms operate through the use of public resources, which are very limited, they need to be managed efficiently. Through the effectively implemented business activities of the municipality, it is possible to obtain additional resources to ensure the needs for the performance of self-government and the production of local public goods or services. Financial resources obtained from businesses can be reused in the expansion of the implemented business activities or in the expansion, reconstruction and modernization of municipal property (Takáč 2006). Municipal firms are, therefore, a fundamental part of the business activities of municipalities. The business activity of the municipality represents a tool for creating suitable economic conditions for the development of business activities in the private sector (Országhová and Gregáñová 2018; Smutka and Steininger 2016). Arapis (2013) states that these firms have helped the government in various ways at all levels, including building infrastructure, stimulating economic growth, providing public services and diversifying government revenue sources. Grossi and Reichard (2008) state that the trend in several European countries is relatively high employment in municipal firms, e.g., in Germany, almost $50 \%$ of the municipality's labor power work in municipal firms, and in Italy, it is almost 30\%. In Sweden, 34\% of the total number of employees of state-owned enterprises work in municipal firms (PWC 2015). Valach and Bumbalová (2020) state that in the Slovak Republic, the largest group (51.23\%) consists of municipal firms with less than 10 employees. Based on this indicator, such firms belong to so-called microfirms. In contrast, there are only five municipal firms with more than 250 employees. In this context, in our research, we focused on the evaluation of the sales of municipal companies in terms of individual identification factors (region, number of employees, municipality size and longevity).

Hypothesis 3 (H3). We assume statistically significant differences in the sales of municipal firms in terms of individual identification factors ( $a$-region and $b$-number of employees).

Hypothesis 4 (H4). We assume a statistically significant linear dependence of the volume of sales of municipal firms on individual identification factors ( $a$ - municipality size and $b$-longevity).

The establishment of a successful business in local self-governments is not only an ambitious but also an important step in maximizing the provision of services at the local level (Mbecke 2015). However, Rundesová (2008) expressed the opinion that many municipalities are in fact "forced" into business activities, which means that they allegedly carry out business activities "voluntarily by force", although ultimately, they increase their welfare. Therefore, according to Halásek et al. (2002), it is necessary for municipalities to make very careful decisions about the business activities of municipalities. The municipal authorities should have access to an analysis of the management of the municipal firm in order to reduce the level of risk to a minimum so that the property of the municipality invested in the joint venture is not impaired. Bumbalová (2011) notes that, among the most frequently used organizational and legal forms of entities that municipalities base on the implementation of business activities, are limited liability companies and joint stock companies. Valach and Bumbalová (2020) state that the vast majority of Slovak 
municipal firms have the legal form of a limited liability company, while in more than $60 \%$, their capital does not exceed EUR 50,000. Sýkora (2021), however, adds that the municipality is not obliged to create a specific liability company or joint stock company as a legal entity for the performance of business activities. Kuoppakangas (2013) also adds that, in accordance with legislation and policies adopted at the municipal level, these firms can use their own resources to support their development goals, even without the consent of the political actors involved, but only within the limits explicitly stated in the statutes. However, according to Kaliňák (2016), it is important to emphasize that the purpose of the business activities of municipal firms should not only be financial profit, but also non-financial profit. This means that their activities should increase the scope and quality of services provided in the framework of public benefit activities. Among some of the benefits of setting up a municipal firm according to Ledecký et al. (2014) are the cheapening and improvement of public services; emergency workers are "always at hand" in case of accidents and emergencies; a source of interpersonal relationship; irreplaceable help in organizing cultural sports and social life; starting and improving the business environment; the use of municipal resources; and the fact that the municipal firm is an important part of the development of the municipality. On the other hand, Rončák and Mateičková (2011) claim that the area of municipal firms is one of the areas that is the least controlled by the public. This increases opportunities for corrupt and non-transparent behavior (e.g., the process of creating firm bodies, rules for hiring firm employees, the method of public procurement and prices of selected commodities) of representatives of municipal firms.

\section{Methodology}

In the conditions of the Slovak Republic, the municipality can conduct business activities as a legal entity in its own name (mainly in the case of smaller municipalities), with the help of a contributory/budgetary organization, or as a business firm established by the municipality. The municipality can also use its property to support the business activities of other entities located in its territory.

The aim of this paper was the economic evaluation of the management of municipal firms at the level of rural local self-governments under the conditions of the Slovak Republic on the basis of selected available economic indicators-profitability and volume of sales. At the same time, we analyzed the relationship between these economic indicators and the size of the firm, longevity, or number of employees. For this purpose, we set research hypotheses, through which we tested the relationships between individual factors or differences based on them.

To answer the research question using the second economic indicator (volume of sales), one research hypothesis (H2) is defined, which is verified by means of four partial hypotheses focusing on individual identification factors as follows:

The individual hypotheses are processed in a dataset of 137 municipal firms with the following characteristics (see Table 1).

Table 1. Description of the selected variables.

\begin{tabular}{cccccc}
\hline Variable & Year & Average & Median & Coefficient of Variance (\%) & Range \\
\hline \multirow{6}{*}{ Profit } & 2015 & 10,796 & 626 & 558.42 & 649,672 \\
& 2016 & $13,680.7$ & 872 & 524.98 & 651,041 \\
& 2017 & $13,342.7$ & 798 & 572.60 & 875,153 \\
& 2018 & $12,021.1$ & 852 & 652.28 & 704,251 \\
\multirow{5}{*}{ Sales } & 2019 & 8299.64 & 131 & 906.48 & 668,581 \\
& 2015 & 238,182 & 80,129 & 146.24 & $1.87 \times 10^{6}$ \\
& 2016 & 245,704 & 89,364 & 142.69 & $1.83 \times 10^{6}$ \\
& 2017 & 260,714 & 94,816 & 148.43 & $1.93 \times 10^{6}$ \\
& 2018 & 275,617 & 87,213 & 152.65 & $2.43 \times 10^{6}$ \\
\hline
\end{tabular}

Source: own processing. 
Defining individual research hypotheses determines the apparatus of mathematicalstatistical methods that are used for their evaluation. The basis was the verification of the normal distribution by means of the Shapiro-Wilk test (see Vavrek et al. 2020):

$$
S W=\frac{\left(\sum u_{i} x_{i}\right)^{2}}{\sum u_{i}^{2} \sum\left(x_{i}-\bar{x}\right)^{2}}
$$

where: $u_{i}$ constant;

$x_{i}$ value of $i$-th statistical unit;

$\bar{x}$ average value of variable.

Due to the nature of the data for the evaluation of partial hypotheses (H1a, H1b, H3a, H3b), the Kruskal-Wallis test was used:

$$
Q=\frac{12}{n(n-1)} \sum_{i=1}^{I} \frac{T_{i}^{2}}{n_{i}}-3(n+1)
$$

where: nnumber of observations and sample size, respectively;

$n_{i}$ number of observations in $i$-th group;

$T_{i}^{2}$ total number of orders in the $i$-th group.

Due to the nature of the data for the evaluation of partial hypotheses (H2a, H2b, H4a, $\mathrm{H} 4 \mathrm{~b})$, a simple regression linear model calculated using the least squares method was used, while the explanatory value of the regression linear model thus created was verified using the coefficient of determination:

$$
R^{2}=\frac{\sum_{i=1}^{n}\left(y_{i}-\hat{y}_{i}\right)^{2}}{\sum_{i=1}^{n}\left(y_{i}-\bar{y}_{i}\right)^{2}}
$$

where: $y_{i}$ measured value of dependent variable;

$\hat{y}_{i}$ estimated value of dependent variable;

$\bar{y}_{i}$ estimated value of dependent variable.

All analyses and calculations were processed using MS Excel, Statistica 13.4 and Statgraphics XVIII.

The reason for choosing rural municipalities is the fact that according to the OECD, the Slovak Republic is a rural country and the majority of the population lives in the countryside. This is also confirmed by Table 2, which shows that of the total number of municipalities in the Slovak Republic (2890), rural municipalities make up 95.33\%, which represents 2755 municipalities out of the total number. There are 2,526,748 inhabitants in

\begin{tabular}{|c|c|c|}
\hline Size Group & Number of Municipalities & Number of Inhabitants \\
\hline 199 inhabitants or less & 415 & 51,743 \\
\hline From 200 to 499 inhabitants & 710 & 247,719 \\
\hline From 500 to 999 inhabitants & 755 & 538,214 \\
\hline From 1000 to 1999 inhabitants & 570 & 800,062 \\
\hline From 2000 to 4999 inhabitants & 305 & 889,010 \\
\hline From 5000 to 9999 inhabitants & 63 & 425,207 \\
\hline From 10,000 to 19,999 inhabitants & 34 & 480,213 \\
\hline From 20,000 to 49,999 inhabitants & 28 & 799,759 \\
\hline From 50,000 to 99,999 inhabitants & 8 & 549,627 \\
\hline From 100,000 and more inhabitants & 2 & 676,319 \\
\hline Total number of municipalities & 2890 & $5,457,873$ \\
\hline Total number of municipalities up to 5000 inhabitants (rural municipalities) & 2755 & $2,526,748$ \\
\hline $\begin{array}{l}\% \text { share of municipalities up to } 5000 \\
\text { inhabitants on total number of municipalities }\end{array}$ & 95.33 & 46.30 \\
\hline
\end{tabular}
rural municipalities, who represent $46.30 \%$ of the total inhabitants of the Slovak Republic.

Table 2. Number of municipalities and number of inhabitants in municipalities in Slovak Republic on 31 December 2019. 
In addition to being a rural country, the Slovak Republic is also characterized by a fragmented settlement structure (see also Vavrek 2015). This is also confirmed by Table 3, which shows that in terms of the number of small municipalities with less than 5000 inhabitants, most of them are located in the Prešov region, while the least rural municipalities are in the Bratislava region. The presence of a large number of small rural municipalities also has an impact on the overall economy of the region. In the Bratislava region, where the least small municipalities are located, the largest regional GDP per capita is generated. The Prešov region, with the largest number of municipalities with less than 5000 inhabitants, generates three times less regional GDP compared to the Bratislava region.

Table 3. Demographic and economic characteristics of Slovak regions on 31 December 2019.

\begin{tabular}{|c|c|c|c|c|c|}
\hline Region & $\begin{array}{l}\text { Number of Rural } \\
\text { Municipalities }\end{array}$ & $\begin{array}{c}\text { Number of } \\
\text { Inhabitants in Rural } \\
\text { Municipalities }\end{array}$ & $\begin{array}{l}\text { Number of Municipal } \\
\text { Firms in Rural } \\
\text { Municipalities }\end{array}$ & $\begin{array}{l}\text { Regional GDP } \\
\text { (EUR Million) }\end{array}$ & $\begin{array}{l}\text { Regional GDP } \\
\text { Per Inhabitant } \\
\text { (EUR) }\end{array}$ \\
\hline Bratislava region (BA) & 61 & 110,955 & 14 & $26,379.564$ & $50,428.546$ \\
\hline Trnava region (TT) & 236 & 308,038 & 34 & $10,840.655$ & $24,395.099$ \\
\hline Trenčín region (TN) & 261 & 277,048 & 50 & 8109.887 & $17,600.876$ \\
\hline Nitra region (NR) & 337 & 360,407 & 28 & 9940.255 & $18,697.530$ \\
\hline Žilina region (ZA) & 293 & 337,077 & 34 & $10,658.802$ & $19,578.118$ \\
\hline Banská Bystrica region (BB) & 496 & 315,705 & 58 & 8175.239 & $16,064.697$ \\
\hline Prešov region $(\mathrm{PO})$ & 646 & 451,834 & 61 & 8753.769 & $13,468.749$ \\
\hline Košice region (KE) & 425 & 365,684 & 39 & $11,007.006$ & $17,459.668$ \\
\hline
\end{tabular}

Source: Statistical Office of the Slovak Republic, own processing.

In these rural municipalities (up to 5000 inhabitants), a total of 318 municipal enterprises were registered in 2021, based on data from the Register of Financial Statements. Most municipal firms were based in the Prešov region, and the least number in the Bratislava region. However, the base file database also included municipal firms with an incomplete range of data, municipal firms in bankruptcy or municipal firms that have already ceased to exist. For this reason, we decided to analyze a sample of municipal firms in the time period 2015-2019. A sample consisting only of municipal firms that fulfilled the following parameters was used: data are available for the entire reference time period 2015-2019; the entity is not in bankruptcy; the subject did not cease to exist on 1 January 2021 and is performing its activity, i.e., is active. The number of municipal firms which fulfilled all of the abovementioned parameters was 137.

\section{Results and Discussion}

In the conditions of Slovakia, the municipality as a legal entity has the right to conduct business through any form in accordance with act no. 513/1991 Coll.-Commercial Code as amended. Pursuant to the provisions of the Commercial Code, as of its entry into force on 1 January 1992, commercial firms may also be established by municipalities. The municipality can establish a business firm as the sole shareholder or as the sole companion. In such a case, the competence of the general meeting is performed by the statutory body of the municipality, which is the mayor of the municipality. The advantage of this form of management is that the municipality, based on the use of its own property for business purposes, can simultaneously ensure revenues to the municipal budget and also solve the problem of unemployment. The problem with this form of conducting business with municipal property is the big concentration of decision-making power of the mayor, who, on the one hand, acts as the statutory body of the municipality and, on the other hand, acts as the statutory body of the firm. It follows that, in the process of such a two-pronged decision, he may give priority to his private interest over the public interest. This form of business can lead to the targeted privatization of municipal property. In practice, only capital firms are appropriate for municipalities. According to the Commercial Code, a limited liability company can also be established by one person, and the company can have a maximum of 50 partners. The company is responsible for its liabilities with all its assets, and the partner is liable for the company's liabilities up to the amount of its 
unpaid deposit entered in the Commercial Register. The value of the share capital must be at least EUR 5000; this share capital consists of cash and non-cash deposits, and the value of the shareholder's contribution must be at least EUR 750. If the company is founded by one founder, the base is a founding agreement; if there are several founders, then a partnership agreement is written. In the case of the participation of a municipality in such a company, the founding or social contract is signed by the mayor only with the consent of the municipal council. In this context, we consider it necessary to state that in some companies in which the municipality has an ownership interest, a larger number of partners in the position of various natural and legal persons can participate. Several companies are also registered, where only municipalities are the exclusive partners, in various numbers. An example of a large number of partners can be a company registered by the District Court of Nitra, which unites up to 12 municipalities, and whose subjects of business are mainly activities necessary for municipalities, e.g., waste management, construction activity, operation and maintenance of water supply and sewerage network. Other companies are registered by the District Court of Košice I, which concentrates 18 municipalities and whose subject of business is, in addition to waste management and production (Hudec 2011). Although these companies operate in a competitive market environment, their important mission is often to provide services to the population. Their purpose is not only financial gain, but also non-financial profit. This means that, in addition to financial gain, their activities can increase the scope and quality of services provided in the framework of public benefit activities. However, if they focused only on providing services to the inhabitants, and managing loss, the result would be the devaluation of municipal property and eventual bankruptcy. The profitability of municipal firms in individual regions of the Slovak Republic in 2019 is shown in Figure 1. We can observe differences mainly at the level of individual entities, not the group as a whole, which captures the occurrence of remote (or extreme) observations in all regions except the Bratislava region (BA).

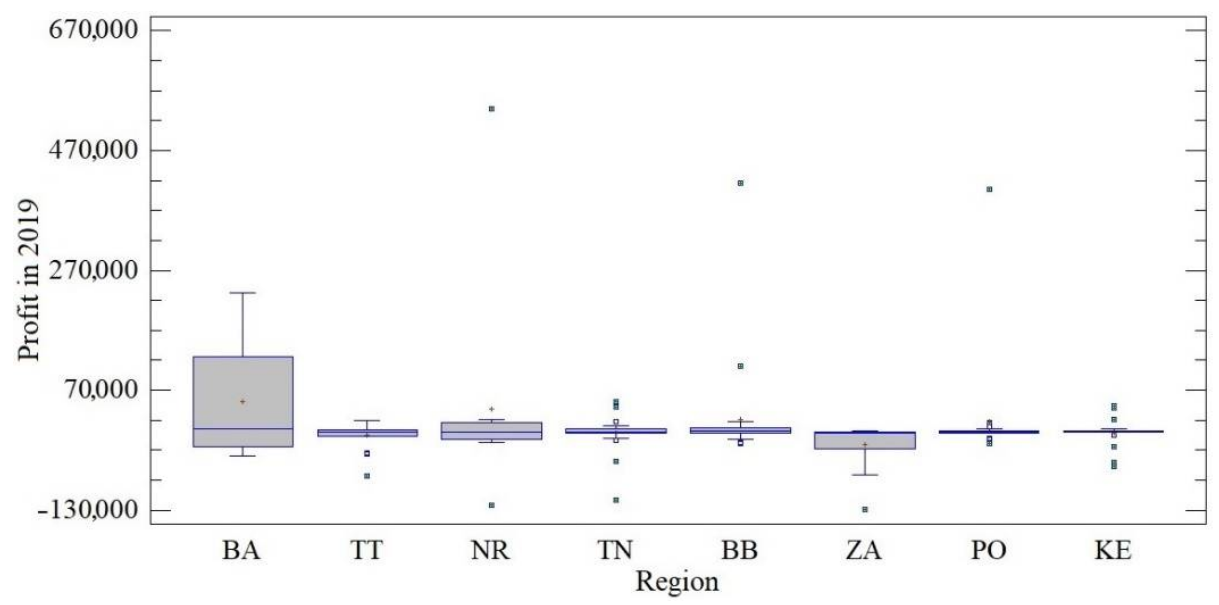

Figure 1. Profitability of municipal firms: by region, 2019 (hypothesis 1a). Source: own processing.

Statistically significant differences using the Kruskal-Wallis test (Table 4) indicate a different situation in the individual analyzed years, while in 2018 and 2019, the differences between the regions were not demonstrated.

Figure 2 shows the profitability of municipal firms according to the number of employees in 2019 (or size groups). The majority of firms are relatively balanced, but graphic differences can be identified in the number of remote (or extreme) values in individual groups, and in the municipal firms with significantly better or worse results compared to the results of others in the given size group. 
Table 4. Results of verification of research hypothesis 1a.

\begin{tabular}{cc}
\hline Year & Kruskal-Wallis Test \\
\hline 2015 & $\mathrm{Q}=9.106 ; p=0.245$ \\
2016 & $\mathrm{Q}=21.024 ; p<0.05$ \\
2017 & $\mathrm{Q}=16.180 ; p<0.05$ \\
2018 & $\mathrm{Q}=0.229 ; p=0.265$ \\
2019 & $\mathrm{Q}=3.920 ; p=0.799$ \\
\hline
\end{tabular}

Source: own processing.

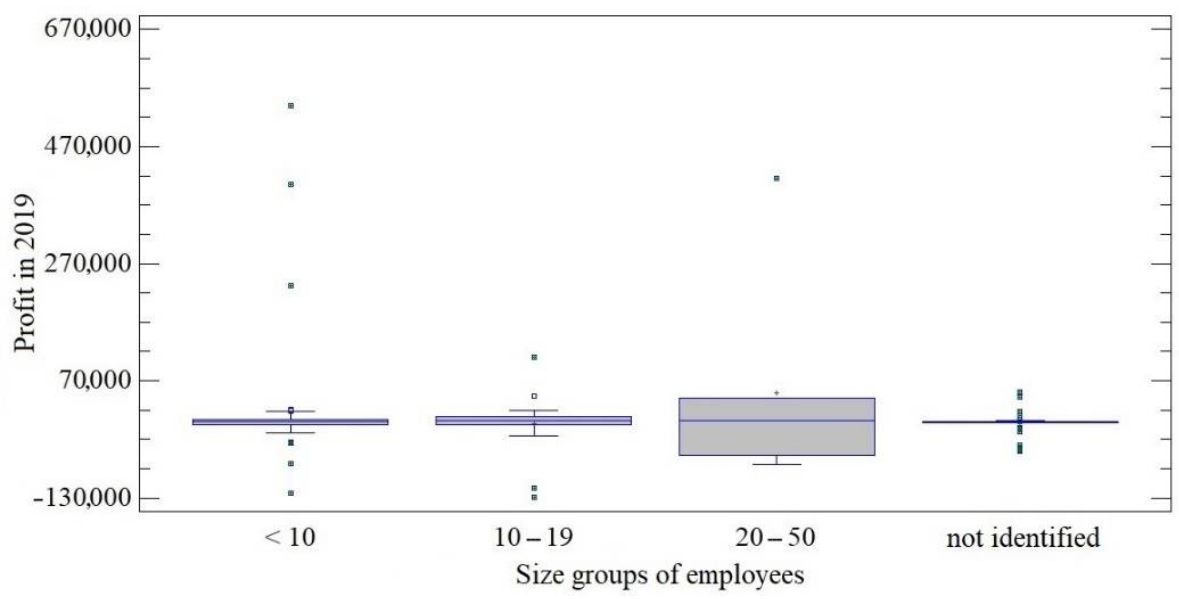

Figure 2. Profitability of municipal firms by number of employees in 2019 (hypothesis 1b). Source: own processing.

Differences in the mean value of profitability of individual groups of municipal firms (using the Kruskal-Wallis test) proved to be statistically significant only in the first of the evaluated years - in 2015. In other years, we did not register differences between municipal firms (see Table 5).

Table 5. Results of verification of research hypothesis $1 \mathrm{~b}$.

\begin{tabular}{cc}
\hline Year & Kruskal-Wallis Test \\
\hline 2015 & $\mathrm{Q}=9.639 ; p<0.05$ \\
2016 & $\mathrm{Q}=6.879 ; p=0.075$ \\
2017 & $\mathrm{Q}=4.807 ; p=0.186$ \\
2018 & $\mathrm{Q}=7.508 ; p=0.057$ \\
2019 & $\mathrm{Q}=2.754 ; p=0.431$ \\
\hline
\end{tabular}

Source: own processing.

Based on the above, it is not possible to confirm partial research hypothesis $1 \mathrm{a}$, which means that differences in the profitability of municipal firms from the point of view of the region in which the municipal firm operates are not statistically significant. The same conclusion can also be stated in the case of partial research hypothesis $1 \mathrm{~b}$, when the differences in the profitability of municipal firms in terms of the number of employees are also not statistically significant. Based on this evaluation of partial research hypotheses $1 \mathrm{a}$, $1 b$, we also reject research hypothesis 1 .

In partial research hypothesis $2 \mathrm{a}$, we assume the dependence of the profitability of municipal firms on the size of the municipality in which the municipal firm is located, while the degree of this dependence in 2019 is shown in Figure 3. This dependence can be expressed by a linear regression model with Profit $=0.92936 \times$ number inhabitants $\left(\mathrm{R}^{2}=0.09 \%\right)$. 


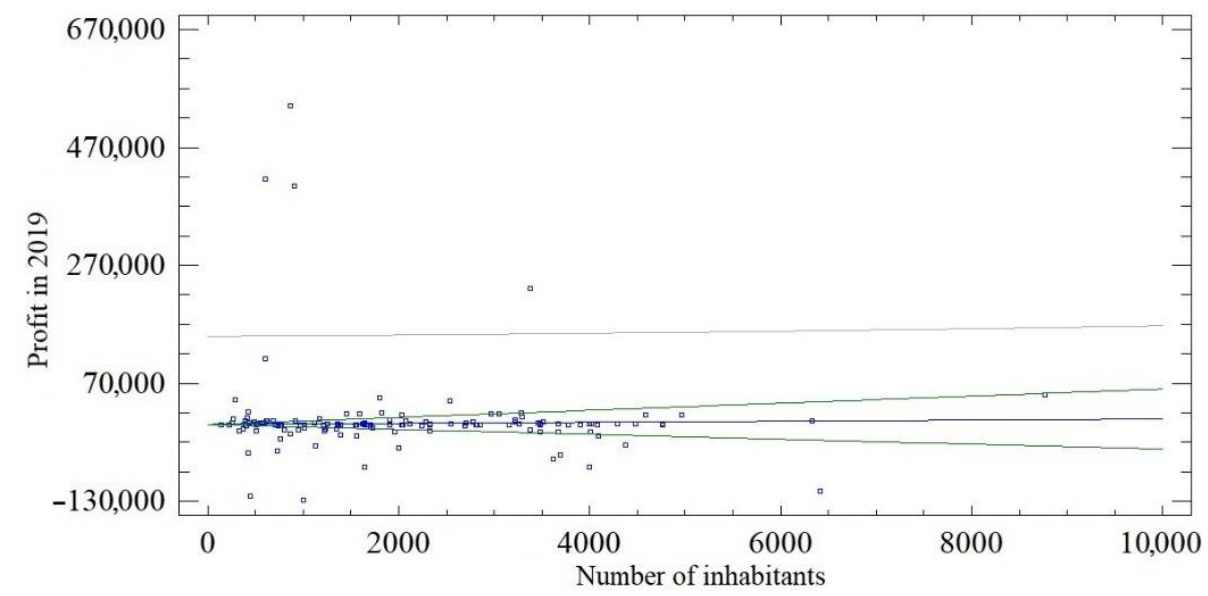

Figure 3. Dependence of profitability of municipal firms on the size of the municipality in 2019 (hypothesis 2a). Source: own processing.

In the individual analyzed years 2015-2019, we observe similar results, while each time the dependence of profitability on the number of inhabitants is positive, it means as the population of the municipality grows, so does the profitability of municipal firms in this municipality (Table 6). However, the regression models themselves reach a low significance value expressed by the coefficient of determination.

Table 6. Results of verification of research hypothesis $2 \mathrm{a}$.

\begin{tabular}{ccc}
\hline Year & Linear Regression Function & $\mathbf{R}^{\mathbf{2}}(\mathbf{\%})$ \\
\hline 2015 & Profit $=3.1774 \times$ number of inhabitants & 1.70 \\
2016 & Profit $=3.88885 \times$ number of inhabitants & 1.78 \\
2017 & Profit $=3.54442 \times$ number of inhabitants & 1.32 \\
2018 & Profit $=1.61885 \times$ number of inhabitants & 0.26 \\
2019 & Profit $=0.92936 \times$ number of inhabitants & 0.09 \\
\hline
\end{tabular}

Source: own processing.

Within the second partial research partial hypothesis $2 b$, we assume an increase in profitability together with an increase in the time of operation of the municipal firm on the market-its longevity. The results in 2019 shown in Figure 4 and the regression function $\mathrm{P}_{2019}=1.84035 \times$ longevity indicate a positive dependence, which is, however, influenced by other factors that are not included in this model $\left(R^{2}=2.74 \%\right)$.

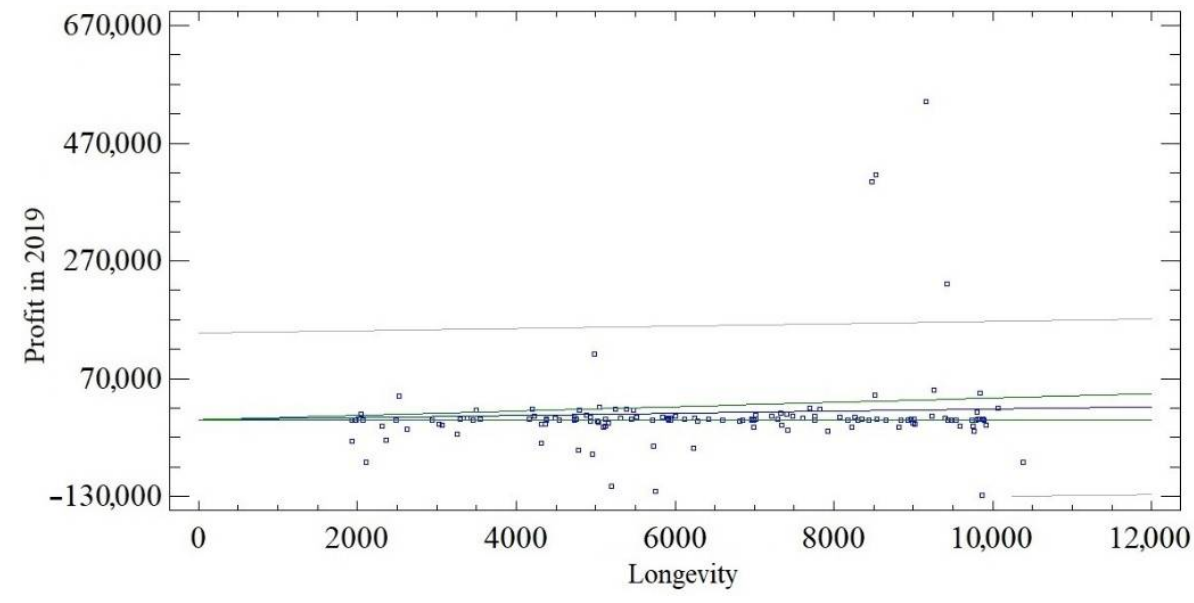

Figure 4. Dependence of profitability of municipal firms on its longevity in 2019. (hypothesis 2b). Source: own processing. 
As in the previous case, in the individual analyzed years, 2015-2019, we can see similar results, while each time the dependence of profitability on the longevity of municipal firms on the market is positive, this means that the number of days a municipal firm operates on the market increases its own profitability (Table 7). Such an interpretation of the results is also influenced by their low explanatory power, as the variability of the dependent variable is significantly influenced by other factors.

Table 7. Results of verification of research hypothesis $2 b$.

\begin{tabular}{clc}
\hline Year & Linear Regression Function & $\mathbf{R}^{\mathbf{2}} \mathbf{( \% )}$ \\
\hline 2015 & Profit $=2.11042 \times$ longevity & 5.49 \\
2016 & Profit $=2.55875 \times$ longevity & 5.67 \\
2017 & Profit $=2.19967 \times$ longevity & 3.72 \\
2018 & Profit $=2.37349 \times$ longevity & 4.14 \\
2019 & Profit $=1.84035 \times$ longevity & 2.73 \\
\hline
\end{tabular}

Source: own processing.

Based on the above, especially very low values of the coefficient of determination $\left(\mathrm{R}^{2}\right)$, it is not possible to confirm the linear dependence of the profitability of municipal firms on the size of the municipality in which the municipal firm is located, and so partial research hypothesis 2 a cannot be confirmed. We also observe very low values of the coefficient of determination in the case of the second partial research hypothesis $2 b$, so similarly, partial research hypothesis $2 \mathrm{~b}$ cannot be confirmed. Based on this evaluation of partial research hypotheses $2 a, 2 b$, we also reject research hypothesis 2 .

The volume of sales of municipal firms in 2019 by individual regions is shown in Figure 5. With the exception of the Bratislava region (BA), we observe municipal firms in each of the regions, whose results deviate from other results in individual regions, which can be described as remote and extreme values, respectively.

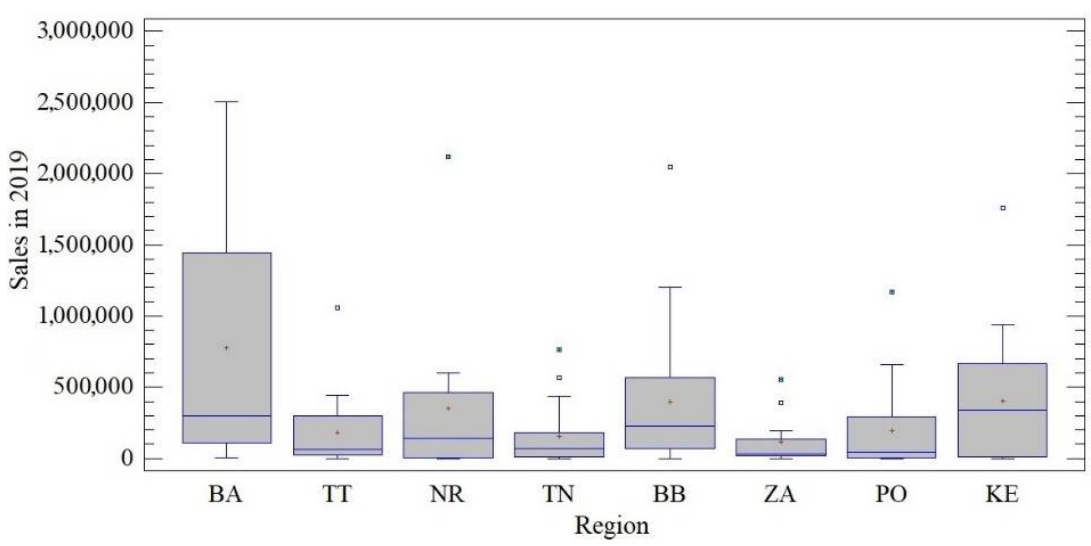

Figure 5. Volume of sales of municipal firms by region, 2019 (hypothesis 3a). Source: own processing.

The occurrence of such municipal firms with different results persists across the years 2015 to 2019, which we label as homogeneous. The differences between the individual regions did not prove to be statistically significant or stable, which we deduce from the absolute values captured in Table 8 .

Based on Figure 6, we can state that with the growth of the number of employees (size group), the volume of sales of municipal firms also increases. The results, with the exception of the first group (up to 10 employees), are relatively balanced, as we do not observe the occurrence of remote (or extreme) results. 
Table 8. Results of the verification of research hypothesis 3a.

\begin{tabular}{ll}
\hline Year & Kruskal-Wallis Test \\
\hline 2015 & $\mathrm{Q}=12.015 ; p=0.100$ \\
2016 & $\mathrm{Q}=12.274 ; p=0.091$ \\
2017 & $\mathrm{Q}=11.775 ; p=0.108$ \\
2018 & $\mathrm{Q}=10.407 ; p=0.166$ \\
2019 & $\mathrm{Q}=10.043 ; p=0.186$ \\
\hline
\end{tabular}

Source: own processing.

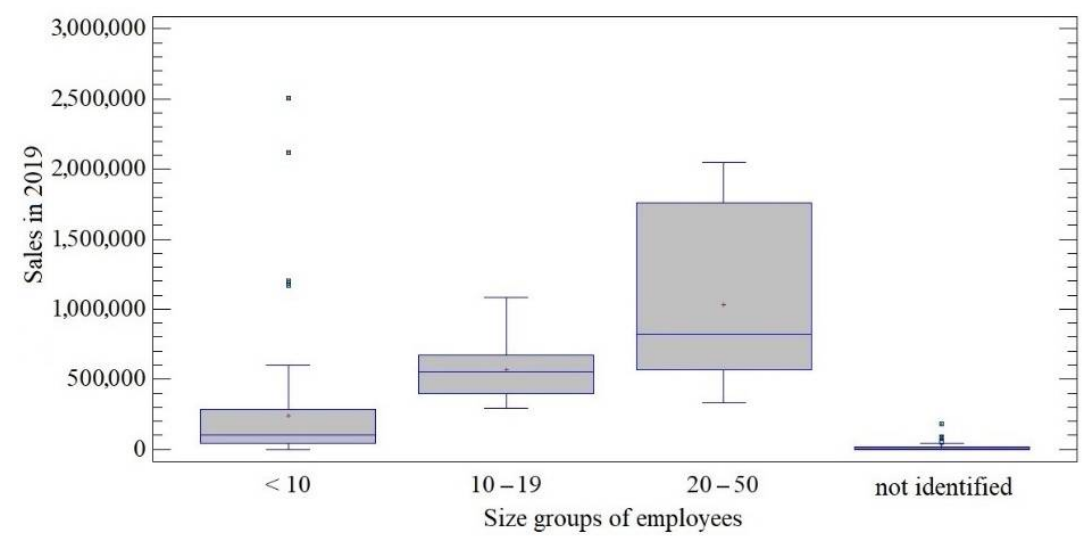

Figure 6. Volume of sales of municipal firms by number of employees in 2019 (hypothesis 3b). Source: own processing.

Differences in the mean value of the volume of sales of individual size groups (using the Kruskal-Wallis test) proved to be statistically significant in each of the evaluated years, 2015, 2016, 2017, 2018 and 2019. The size of the municipal firm is, therefore, a factor influencing the volume of sales (see Table 9).

Table 9. Results of verification of research hypothesis $3 b$.

\begin{tabular}{ll}
\hline Year & Kruskal-Wallis Test \\
\hline 2015 & $\mathrm{Q}=74.183 ; p<0.05$ \\
2016 & $\mathrm{Q}=89.893 ; p<0.05$ \\
2017 & $\mathrm{Q}=87.801 ; p<0.05$ \\
2018 & $\mathrm{Q}=86.206 ; p<0.05$ \\
2019 & $\mathrm{Q}=87.100 ; p<0.05$ \\
\hline
\end{tabular}

Source: own processing.

Based on the above, it is not possible to confirm partial research hypothesis 3a-the differences in the volume of sales of municipal firms from the point of view of the region in which the municipal firms operate are not statistically significant. The exact opposite conclusion can be stated in the case of research hypothesis $3 b$-the differences in the volume of sales of municipal firms in terms of the number of employees are statistically significant. Therefore, based on the evaluation of partial research hypotheses $3 a, 3 b$, it is not possible to unequivocally reject or confirm research hypothesis 3 . This conclusion is also confirmed by the research of municipal firms in Sweden. Municipalities in this country employ on average $18 \%$ of the country's total workforce. In some municipalities, where municipal firms focus on social services in relation to the elderly or children, this share can be much higher, even at the level of $30 \%$. If municipalities do not create municipal firms, but create conditions for business activities of private firms, this share is much lower. However, in such a case, there is no statistically significant correlation between employment in municipalities and employment in the vicinity of the municipality in terms of population density (Fölster et al. 2016). The situation is similar in all historical regions of Poland, 
where more than four-fifths of local self-governments have taken measures to increase the number of local jobs, two-fifths of which were municipalities in Greater Poland. This area thus pursued a more dynamic development policy through the development of municipal business activity (Gorzelak 2019). Within partial research hypothesis 4a, we assume the dependence of the volume of sales of municipal firms on the size of the municipality in which the municipal firm is located (as well as in the case of their profitability). The degree of this dependence in 2019 is shown in Figure 7, while it can be expressed by a linear regression model with a function in the form $\mathrm{S}_{2019}=85.1138 \times$ number of inhabitants of the municipality $\left(\mathrm{R}^{2}=18.07 \%\right)$.

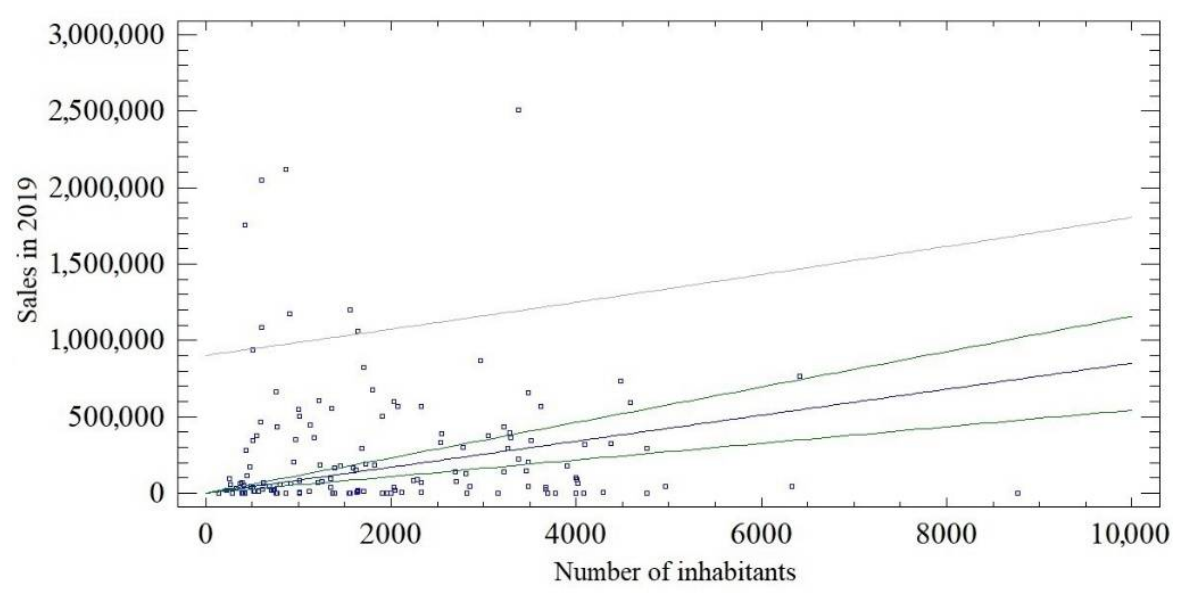

Figure 7. Dependence of profitability of municipal enterprises on the size of the municipality in 2019 (hypothesis 4a). Source: own processing.

In the individual analyzed years, 2015-2019, we observe similar results, while each time the dependence of profitability on the number of inhabitants is positive, it means that with the growth of the population in the municipality, the volume of sales of municipal firms in this municipality is also growing (Table 10). Low values of the coefficient of determination $\left(R^{2}\right)$ indicate that the volume of sales of municipal firms is significantly influenced by other factors, not only the number of inhabitants in the municipality.

Table 10. Results of verification of research hypothesis $4 a$.

\begin{tabular}{clc}
\hline Year & Linear Regression Function & $\mathbf{R}^{\mathbf{2}} \mathbf{( \% )}$ \\
\hline 2015 & Sales $=76.7863 \times$ number of inhabitants & 20.89 \\
2016 & Sales $=79.7422 \times$ number of inhabitants & 21.88 \\
2017 & Sales $=81.4638 \times$ number of inhabitants & 19.23 \\
2018 & Sales $=88.4628 \times$ number of inhabitants & 19.51 \\
2019 & Sales $=85.1138 \times$ number of inhabitants & 18.07 \\
\hline
\end{tabular}

Source: own processing.

The second partial research hypothesis $4 \mathrm{a}$ assumes an increase in the volume of sales together with an increase in the time of operation of the municipal firm on the market-its longevity. The results in 2019 shown in Figure 8 and the regression function $S_{2019}=42.5075$ $\times$ longevity illustrate positive dependence, which, however, can be marked as partial $\left(R^{2}=33.02 \%\right)$.

In the case of partial research hypothesis $4 \mathrm{~b}$, we can see similar results in the individual analyzed years, 2015-2019, while the dependence of the volume of sales on the time of operation on the market (longevity of municipal firm) is significantly positive. As the number of days a municipal firm operates on the market increases, so does its profitability (Table 11). 


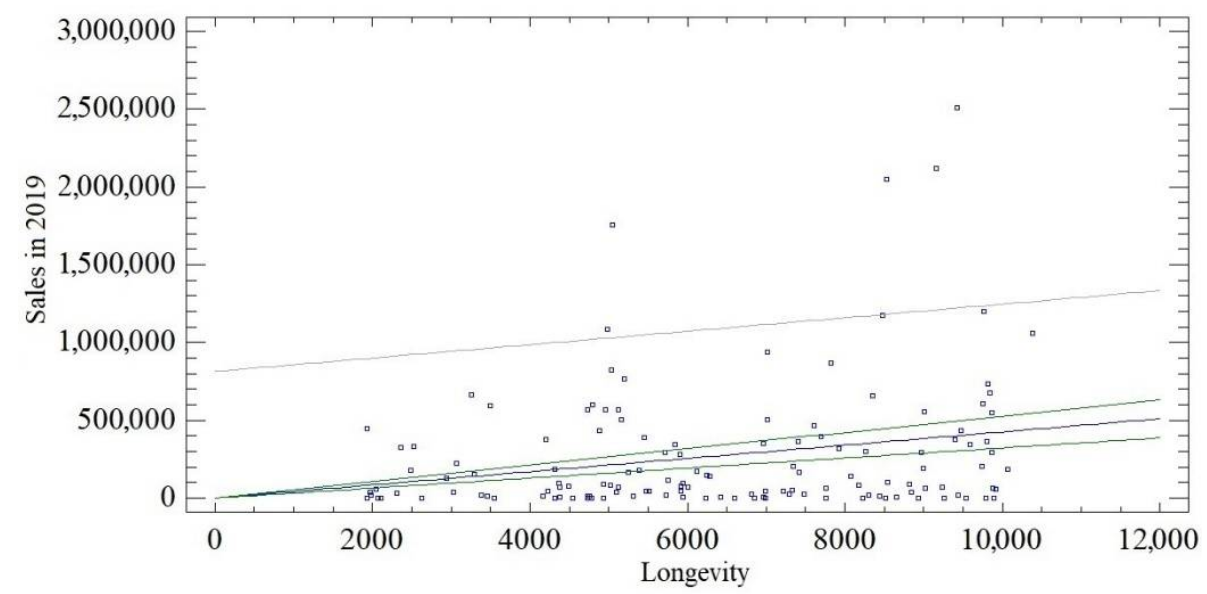

Figure 8. Dependence of the volume of sales of municipal firm on its longevity in 2019 (hypothesis 4b). Source: own processing.

Table 11. Results of verification of research hypothesis $4 \mathrm{~b}$.

\begin{tabular}{ccc}
\hline Year & Linear Regression Function & $\mathbf{R}^{\mathbf{2}} \mathbf{( \% )}$ \\
\hline 2015 & Sales $=38.0766 \times$ longevity & 37.63 \\
2016 & Sales $=38.5564 \times$ longevity & 37.48 \\
2017 & Sales $=40.6697 \times$ longevity & 35.11 \\
2018 & Sales $=43.1727 \times$ longevity & 34.05 \\
2019 & Sales $=42.5075 \times$ longevity & 33.02 \\
\hline
\end{tabular}

Source: own processing.

Based on the above, especially the very low values of the coefficient of determination $\left(\mathrm{R}^{2}\right)$, it is not possible to confirm the linear dependence of the volume of sales of municipal firms on the size of the municipality in which the municipal firm is located. Therefore, partial research hypothesis 4a cannot be confirmed. The same conclusions are drawn in the case of the second partial research hypothesis, when we observe low values of the coefficient of determination, so partial research hypothesis $4 \mathrm{~b}$ cannot be confirmed. The volume of sales of municipal firms with the population of the municipality as well as the time of operation on the market is growing, but these are not the only factors on which these results depend. Based on such an evaluation of partial research hypotheses $4 a, 4 b$, we also reject research hypothesis 4 .

\section{Conclusions}

In the Slovak Republic, rural areas represent $86 \%$ of the territory in which $43 \%$ of the population live. It is a heterogeneous area in which natural, human and economic resources are used. The Slovak countryside is characterized by a highly diverse physical environment, a wide range of economic activities, a characteristic network of social relations and centuries-old cultural traditions.

Economic activities in rural municipalities are developed not only by the private sector, but also by the municipalities themselves through their municipal firms. Analyses showed that in 2021, 318 municipal firms had their headquarters in rural municipalities. In the analysis of mutual relations of the most important economic indicators, profit and sales and number of employees, longevity or size, we found that differences in the profitability and sales volume of municipal firms from the perspective of the region in which the municipal firm operates are not statistically significant. It is also not possible to confirm the linear dependence of the profitability of municipal firms on the size of the municipality in which the municipal firm is located. However, it is possible to confirm the positive dependence between the growth of the population of the municipality and the growth of sales of municipal firms based in this municipality. However, low values of the coefficient 
of determination $\left(R^{2}\right)$ indicate that the volume of sales of municipal firms is significantly affected by other factors, not only the number of inhabitants of the municipality.

The results of the analysis confirm the fact that general enterprises are specific in comparison with traditional business entities, and it is not possible to analyze them with the general common ratio indicators of financial analysis, such as profitability indicators: ROE and ROA; indicators of activity; indicators of indebtedness; market value or liquidity. These indicators are of large importance from the point of view of comparing business entities, but from the point of view of municipal firms, they are not sufficiently informative, as the reasons for establishing municipal enterprises are different from those of commercial firms. While the business sector creates firms that it knows will make a profit as they provide services and goods that are in demand, it is different for municipal firms. Municipal firms often also provide services that the private sector does not want to provide precisely due to low profitability (e.g., small community services). Municipal firms are established primarily for the purpose of providing services to the population and creating jobs, and only then are they created for profit. The profit and revenue indicators that we analyzed in the case of municipal firms are important from the point of view of their sustainability, but also from the point of view of the financial management of municipalities. Through revenues, municipal firms cover their costs and thus reduce their dependence on the municipal budget, as in the event of a decrease in revenue, the municipality usually subsidizes such enterprises through subsidies from its budget. There are similar differences in the case of profit. Part of the profit is invested by municipal firms and part of it flows into the municipal budget. In this way, municipal firms play a significant role in the socio-economic development of the municipality.

Although the business activity of rural municipalities implemented through municipal firms enables revenues to the local budget, the area of business with municipal property is generally not given much attention under the conditions of the Slovak Republic. The reason for this is that there is no system for classifying firms owned by local self-governments. Likewise, legislation at the national but also at the local level does not recognize the concept of a municipal firm and its operation. The results of the analysis confirm that municipal firms are an important part of the local economy and, therefore, it would be appropriate to legislate the existence and functioning of municipal firms as a special form of business with local self-government property. As inspiration for legislation, we recommend EU legislation, which defines the concept of a public firm in Articles 106 and 345, Treaty on the Functioning of the EU, as a firm over which public authorities have a direct or indirect dominant influence.

The results of the analysis also showed that municipal firms, in addition to revenues to the local budget, also create employment in the municipality with a direct impact on local economic development. Nevertheless, insufficient information is available to assess social and other effects of municipal firms. Research in the field of municipal firms under the conditions of the Slovak Republic is still in its infancy. It can be assumed that in the future, other aspects of municipal business could be included in the model and examined, e.g., the Statistical Classification of Economic Activities is fully compatible with the European classification NACE Revision 2 (SK NACE), property information, demographic data and macroeconomic data of individual regions or districts.

By analyzing selected indicators, we aimed to highlight the specificity of business of municipal firms under the conditions of the Slovak Republic. The database for municipal firms is very limited, despite the fact that these firms are an important factor in the development of the territory. Therefore, in order to make the functioning of municipal firms more efficient, their activities and economic stability should be regularly monitored and evaluated, especially from the point of view of local development. Also, to clearly define the legislation adopted at the local level (resolution of the municipal council and principles on the disposal of municipal property), because the municipality's property creates not only economic but also social conditions in the municipalities. 
Author Contributions: Conceptualization, P.Á. and V.P.; methodology, R.V. and V.P.; software, R.V.; validation, P.Á., R.V., M.D. and V.P.; formal analysis, P.Á., R.V., M.D. and V.P.; investigation, P.Á., R.V., M.D. and V.P.; resources, P.Á., R.V., M.D. and V.P.; data curation, R.V.; writing-original draft preparation, P.Á., R.V., V.P. and M.D.; writing-review and editing, P.Á., R.V., M.D. and V.P.; visualization, P.Á., R.V., M.D. and V.P.; supervision, V.P. and M.D.; project administration, P.Á. and V.P.; funding acquisition, R.V. All authors have read and agreed to the published version of the manuscript.

Funding: This research was funded by the Student Grant Competition in VŠB - Technical University of Ostrava, grant number SP2021/18.

Acknowledgments: We would like to thank the anonymous referees for their useful comments and constructive suggestions.

Conflicts of Interest: The authors declare no conflict of interest.

\section{References}

Aleksee, Ivan A. 2013. Comparative-Legal Analysis of the Legal Responsibility of the Bodies and Official Functionaries of Local Self-Government in Foreign Countries. Middle-East Journal of Scientific Research 17: 1525-31. [CrossRef]

Arapis, Theodoros. 2013. Enterprise Fund Transfers and Their Impact on Governmental Spending and Revenue Patterns of Georgia Municipalities. Journal of Public Budgeting, Accounting \& Financial Management 25: 446-73. [CrossRef]

Babun, Roal'd V. 2020. Local Self-Government in Russia: A New Stage of Municipal Development. Russian Social Science Review 61: 494-507. [CrossRef]

Bumbalová, Monika. 2011. Municipal Firms: Theoretical Background and Terminology. Available online: http://www.slpk.sk/eldo/ 2012/zborniky/001-12/bumbalova.pdf (accessed on 8 May 2021).

Bumbalová, Monika, and Eva Balážová. 2014. Selected Issues of Enterprises with the Municipal Property Share. Paper presented at the 17th International Colloquium on Regional Sciences, Kurdějov, Czech Republic, June 14-16.

Bumbalová, Monika, Eva Balážová, Maroš Valach, Katarína Melichová, Monika Gubáňová, and Denisa Hanáčková. 2021. Využívanie Majetku Miestnych Samospráv na Podnikanie v SR. Nadlac: Editura Ivan Krasko, pp. 1-35.

Clifton, Judith, Daniel Diaz-Fuentes, and Julio Revuelta. 2010. The Political Economy of Telecoms and Electricity Internationalization in the Single Market. Journal of European Public Policy 17: 988-1006. [CrossRef]

Community-Wealth ORG. 2018. Municipal Enterprise. Available online: https://community-wealth.org/strategies/panel/municipal/ index.html (accessed on 2 May 2021).

Fil'a, Milan, Michal Levický, Ladislav Mura, Milan Maroš, and Marcela Korenkova. 2020. Innovations for Business Management: Motivation and Barriers. Marketing and Management of Innovations 4: 266-78. [CrossRef]

Fölster, Stefan, Jansson Li, and Anton N. Gidehag. 2016. The Effect of Local Business Climate on Employment. Journal of Entrepreneurship and Public Policy 5: 2-24. [CrossRef]

Gorzelak, Gzegorz. 2019. Regional and Historic Dimensions of Local Government Performance in Poland. Polish Sociological Review 205: 33-50. [CrossRef]

Grossi, Giuseppe, and Christoph Reichard. 2008. Municipal Corporatization in Germany and Italy. Public Management Review 10: 597-617. [CrossRef]

Halásek, Dušan, Jaroslav Pilný, and Petr Tománek. 2002. Určovaní Bonity obcí. Ostrava: VŠB-TUO, pp. 1-50.

Hudec, Ján. 2011. Právne formy podnikania obcí v Slovenskej republike. Paper presented at the Conference Nové trendy-Nové nápady, Znojmo, Czech Republic, November 5.

Kaliňák, Michal. 2016. Obecné Podniky sú Medzi Službami a Ziskom. Available online: http://www.misokalinak.sk/620-sk/obecnepodniky-su-medzi-sluzbami-a-ziskom/ (accessed on 25 April 2021).

Klimovský, Daniel. 2008. Základy Verejnej Správy. Košice: UPJŠ, pp. 1-44.

Kraftová, Ivana. 2002. Finanční Analýza Municipální Firmy. Prague: C. H. Beck, pp. 1-50.

Kuoppakangas, Päivikki. 2013. Adopting the Municipal Enterprise Form in Finland: Core Dilemmas in the Transformation of Public Healthcare Organizations. Public Organization Review 13: 155-65. [CrossRef]

Ledecký, Vladimír, Marta Bednárová, Lívia Vagnerová, Imrich Holečko, and Stanislav Ledecký. 2014. Manuál pre Starostov a Dobrovol'níkov o Zakladaní Obecných Podnikov. Available online: https:/ / epic-org.eu/wp-content/uploads/2018/10/Manu\% C3\%A11-pre-pre-starostov-a-dobrovo \%C4\%BEn\%C3\%ADkov-o-zakladan\%C3\%AD-obecn\%C3\%BDch-podnikov.pdf (accessed on 25 April 2021).

Levický, Michal, Marta Urbanikova, Jarmila Hudákova, Milan Maroš, and Michaela Štubňova. 2019. Convergence Tendencies in the Conditions of Regions of the Slovak Republic. Paper presented at the 22nd International Colloquium on Regional Sciences, Velké Bílovice, Czech Republic, June 12-16.

Mbecke, Paulin. 2015. Municipal Entrepreneurship: An Alternative Strategy to Promote, Improve and Sustain Service Delivery in Local Governments in South Africa. Corporate Ownership and Control 12: 409-18. [CrossRef] 
Mei, Ciqi, Chen Kang, and Wu Xun. 2016. Local Government Entrepreneurship in China: A Public Policy Perspective. China: An International Journal 14: 3-15. [CrossRef]

Oplotnik, Z. Jan, Bostjan Brezovnik, and Borut Vojinovic. 2012. Local Self-government Financing and Costs of Municipality in Slovenia. Transylvanian Review of Administrative Science 37E: 128-42.

Országhová, Dana, and Radomíra Hornyák Gregáňová. 2018. Changes in the Employment According to the Sectorial Structure of the Regions of Slovakia. Paper presented at the 21st International Colloquium on Regional Sciences, Kurdějov, Czech Republic, June $13-15$.

Osborne, David, and Ted Gaebler. 1993. Reinventing Government. How the Entrepreneurial Spirit is Transforming the Public Sector. Reading: Plume, pp. 1-50.

Pauličková, Alena. 2010. Economic Crisis and Enhanced Competitiveness of Municipalities. Danube 4: 31-39.

Pirošík, Vladimír. 2014. Verejný Záujem v Legislatíve. Available online: https:/ / www.slatinka.sk/assets/verejny-zaujem/Slatinkaverejny-zaujem-analyza-legislativy-V-Pirosik.pdf (accessed on 5 April 2021).

PWC. 2015. State-Owned Enterprises-Catalysts for Public Value Creation? Available online: https://www.pwc.com/gx/en/psrc/ publications/assets / pwc-state-owned-enterprise-psrc.pdf (accessed on 15 April 2021).

Rončák, Ivan, and Monika Mateičková. 2011. Transparentnost’ Spoločností Založených Mestom. Available online: https://www. transparency.sk/wp-content/uploads/2010/01/publikacia-TIS.pdf (accessed on 5 April 2021).

Rundesová, Táňa. 2008. Obce t’ažia z Podnikového Ducha. Available online: https://hnporadna.hnonline.sk/podnikanie/226634 -obce-tazia-z-podnikaveho-ducha (accessed on 5 April 2021).

Smutka, L'uboš, and Michal Steininger. 2016. Rural Population and Agriculture in Relation to Global Economy. Paper presented at the 14th International Scientific Conference on Hradec Economic Days, Hradec Králové, Czech Republic, February 2-3.

Stoilova, Desislava. 2010. Municipal Asset Management in Bulgaria: A Case Study of Municipal Enterprises in Blagoevgrad. Available online: https://www.academia.edu/1765215/MUNICIPAL_ASSET_MANAGEMENT_IN_BULGARIA_A_CASE_ STUDY_OF_MUNICIPAL_ENTERPRISES_IN_BLAGOEVGRAD (accessed on 8 April 2021).

Sýkora, Jozef. 2021. Nakladanie s Majetkom a Majetkovými Právami. Available online: https://prirucka-pre-obce.dashofer.sk/onb/33 /nakladanie-s-majetkom-a-majetkovymi-pravami-uniqueidmRRWSbk196FPkyDafLfWAE_9FpRGSf4zQ_uABB2vYDaj6Hn6 g504xw / ?uri_view_type=5 (accessed on 8 April 2021).

Takáč, Ivan. 2006. Efektívnost' využivania majetku miestnej samosprávy na podnikatel'ské účely. Available online: http://www.slpk. sk/eldo/2007/019_07/takac.pdf (accessed on 8 April 2021).

Valach, Maroš, and Monika Bumbalová. 2020. Entrepreneurial Activities of Municipalities in the Slovak Republic. Paper presented at the 23rd International Colloquium on Regional Sciences, Kurdějov, Czech Republic, June 17-19.

Vavrek, Roman. 2015. Disparity of Evaluation of Municipalities on Region and District Level in Slovakia. Paper presented at the 13th International Scientific Conference on Hradec Economic Days, Hradec Králové, Czech Republic, February 3-4.

Vavrek, Roman, Viera Papcunová, and Juraj Tej. 2020. Evaluation of Financial Management of Towns in relation to Political Cycles using CV-TOPSIS. Lex localis-Journal of Local Self-Government 18: 231-52. [CrossRef]

Vinnari, M. Eija, and Salme Näsi. 2008. Creative Accrual Accounting in the Public Sector: Milking Water Utilities to Balance Municipal Budget and Accounts. Financial Accountability \& Management 24: 97-116. [CrossRef]

Zhang, Ping, Haoshneg Zheng, and Qiang Ren. 2020. The Impacts of Fiscal Decentralization on the Quality of Government in China: A Test of Market-Preserving Federalism at the Provincial Level. Chinese Public Administration Review 11: 89-104. [CrossRef] 